Article

\title{
The Effect of Different Fertilization Treatments on Wheat Root Depth and Length Density Distribution in a Long-Term Experiment
}

\author{
Pavel Svoboda, Gabriela Kurešová ${ }^{\circledR}$, Ivana Raimanová, Eva Kunzová and Jan Haberle * \\ Crop Research Institute, Division of Crop Management System, Drnovská 507, 16106 Prague, Czech Republic; \\ svoboda@vurv.cz (P.S.); kuresova@vurv.cz (G.K.); raimanova@vurv.cz (I.R.); kunzova@vurv.cz (E.K.) \\ * Correspondence: haberle@vurv.cz; Tel.: +420-2330-22-254
}

Received: 1 July 2020; Accepted: 9 August 2020; Published: 9 September 2020

\begin{abstract}
The purpose of this study was to determine the effect of sixty years of contrasting fertilization treatments on the roots of winter wheat (Triticum aestivum L.) at sites with different soil and climate conditions. The depth and length density distribution of the wheat roots were determined between 2014 and 2016 in a crop rotation experiment established in 1955 at three sites: Lukavec, Ćáslav, and Ivanovice (Czech Republic). Three fertilization treatments were examined: Zero fertilization (N0), organic (ORG) fertilization, and mineral (MIN) fertilization. The fertilization, site, and year all had a significant effect on the total root length (TRL). The average TRL per square meter reached 30.2, 37.0, and $46.1 \mathrm{~km}$ with the N0, ORG, and MIN treatments at Lukavec, respectively, which was the site with the lightest soil and the coldest climate. At Časlav and Ivanovice (warmer sites with silt and loamy soils), the average TRL per square meter reached 41.2, 42.4, and $47.7 \mathrm{~km}$ at Čśslav and 49.2, 55.3 , and $62.9 \mathrm{~km}$ at Ivanovice with the N0, MIN, and ORG treatments, respectively. The effect of fertilization on the effective root depth (EfRD), the depth at which the root length density dropped below $2.0 \mathrm{~cm} \mathrm{~cm}^{-3}$, was significant, while the maximum root depth (RMD) was only marginally affected. With the sites and years averaged, the MIN-treated plants showed a greater EfRD $(102.2 \mathrm{~cm})$ in comparison to the N0 $(81.8 \mathrm{~cm})$ and ORG $(93.5 \mathrm{~cm})$ treatments. The N0 treatment showed no signs of an adaptive reaction to the root system, with potential improvement for nutrient acquisition, while optimal fertilization contributed to the potential for resource depletion from the soil profile.
\end{abstract}

Keywords: root length density; subsoil; effective root depth; nitrogen and water depletion zone

\section{Introduction}

Long-term field experiments (LTEs) are typically established to examine the effect of cropping systems (e.g., crop rotations, mineral, and organic fertilization, soil tillage, and management of postharvest residues) upon the crop yield, product quality, and soil properties. The purpose of LTEs is to design productive, effective, and profitable cropping systems and practices, while maintaining long-term soil fertility and minimizing any possible negative impacts on the environment [1-3]. The enormous effort devoted to LTEs is based on the assumption that we can generalize the effects of versatile cropping systems on the environment from the results of these experiments to apply these systems, and to predict their effects under different site conditions. The longest LTE (the Broadbalk Wheat Experiment in Rothamsted, UK) exceeded 160 years [1,4]. The second-longest long-term fertilization trial in the world (the Eternal Rye Experiment in Halle, Germany) was started in 1878 by Julius Kühn [5]. Many such experiments were established around the middle of the 20th century in connection with the intensification of crop production and the increasing importance of soil fertility for new high-yield genotypes [2,5-12]. The importance of data from LTEs has been increasingly 
appreciated in light of the growing concerns about the sustainability of agro-ecosystems and soil quality, with increasing losses of nutrients, surface and groundwater pollution, and the transfer of heavy metals and pesticides to crops. More recently, discussions have also taken place regarding the impacts of climate change and possible approaches to drought adaptation $[1,13,14]$. The analysis and prediction of the impacts of crop systems on the long-term changes in soil organic matter to improve soil quality and to enhance the carbon sink properties of soils are not possible without data from long-term multisite field experiments that apply different rates of mineral and organic fertilizers [1,2,6,15-17].

The examinations of these long-term experiments have mostly concentrated on the aboveground parts of the crops and the arable layer. Little is known about the possible effects of cropping systems on the deep subsoil layers or the entire root system. A well-developed, effective root system has been acknowledged as a stabilizing factor in crop production, especially under less favorable conditions, or the pressures of abiotic stresses [18-20]. Root depth is the basis for calculations of the available water supply, as well as for the prediction of possible onsets of water shortages under various given weather conditions [21]. Root density (RD), root length per soil volume unit, and the distribution of $\mathrm{RD}$ in a soil profile are the traits that are most often used in root field studies. Generally, root system management is rarely considered within farm management [22]. Roots are usually not sampled down to their maximum depth, and too often, the effects of environmental factors and farm practices are only evaluated within the arable and shallow subsoil layers.

The present study could also contribute to more reliable interpretations of the yearly variability of nutrient uptake (especially nitrogen) and the nutrient balance in LTEs. The long-term balance of nutrients, which are calculated from inputs and outputs as an important indicator of long-term sustainability $[11,23,24]$, may be distorted by leaching and gaseous nitrogen losses [25,26]. The roots of most common annual crops, including cereals, oilseed rape, sugar beet, sunflower, and maize (under convenient soil conditions), reach down one meter (or even deeper), and the crops are generally able to deplete the nitrogen and water from the deep subsoil layers [27-31]. Other nutrients (i.e., $\mathrm{K}, \mathrm{Ca}, \mathrm{Mg}$, and $\mathrm{S}$ ions) that are present in the soil solution are also prone to leaching and to possibly being depleted from the subsoil by plant roots. Thus, data regarding the subsoil may contribute to the interpretation of the yearly variability of yields and product quality, as well as to the nutrient uptake and balance in long-term experiments. For example, the nitrogen from fertilizers and the soil supply not used due to drought in one year may be depleted by a crop in the following year if it is not leached during the winter period. Available nitrogen amounts can be estimated via calculations using the water balance, percolation, and the known effective root depth. Root depth data are also important for the calibration and validation of crop models, which are used for the simulation of cropping systems.

In summary, the objective of this study was to determine the effects of long-term contrasting fertilization treatments on root length density distributions and the root depth of wheat at sites with different soil and climate conditions.

\section{Materials and Methods}

\subsection{Location and Soil Characteristics}

The Czech stationary long-term crop rotation experiment (LCRE) was established in 1955 across several sites in the Czech Republic (Figure 1), of which three have lasted until the present: Čáslav (loamy Greyic Phaeozem soil developed on loess), Ivanovice (loamy Chernozem soil on loess), and Lukavec (sandy-loamy Cambisol soil) (Table A1). The experimental design of the LCRE includes treatments of increasing rates of mineral $\mathrm{N}$ fertilizers and farmyard manure. The details and results of the LCRE experiments have been described by various authors for Čáslav [9,32], Ivanovice [8], and Lukavec [33].

All of these experiments are situated on almost flat fields, without any significant surface runoff and erosion. Monthly precipitation and temperatures from the autumn sowing in 2013 until the summer harvest in 2016 are shown in Figure 2, with the long-term data shown in Table A1. The soil 
texture, the proportion of particles $<0.001,0.001-0.01,0.0-0.05$, and $0.05-2.0 \mathrm{~mm}$ were determined in the bulk soil samples from the $\mathrm{N}_{\min }$ soil sampling done in the same fields.

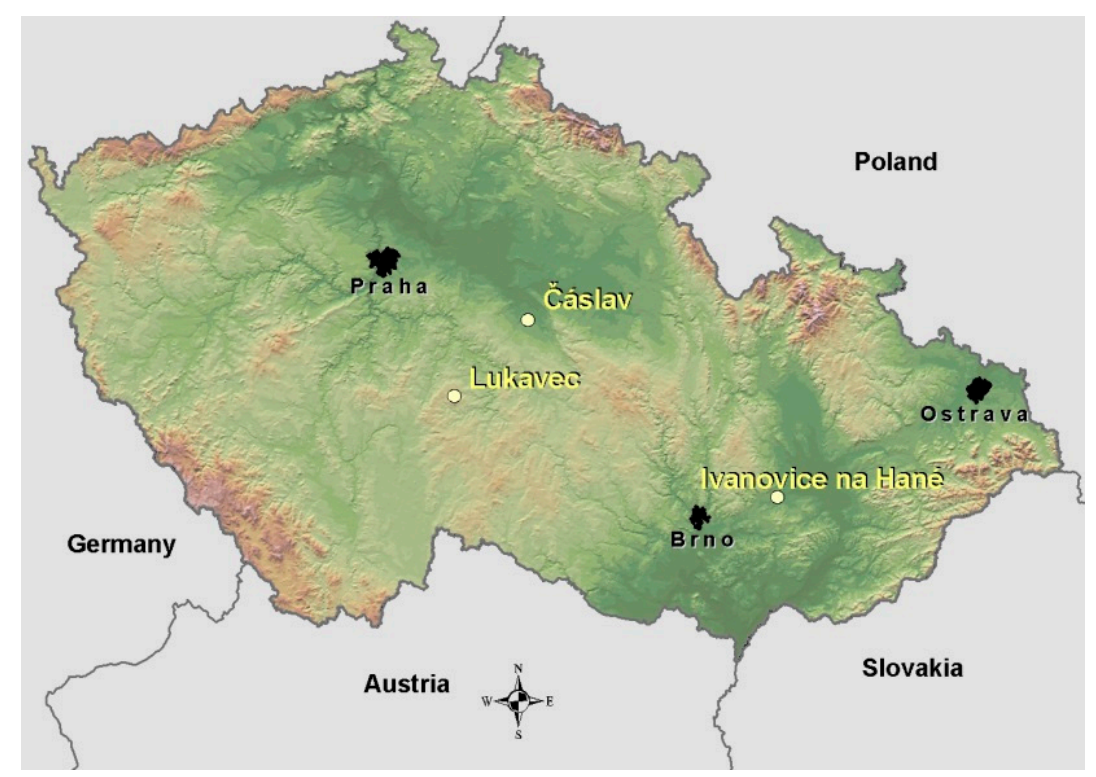

Figure 1. Map of the locations of the long-term experiments in the Czech Republic.
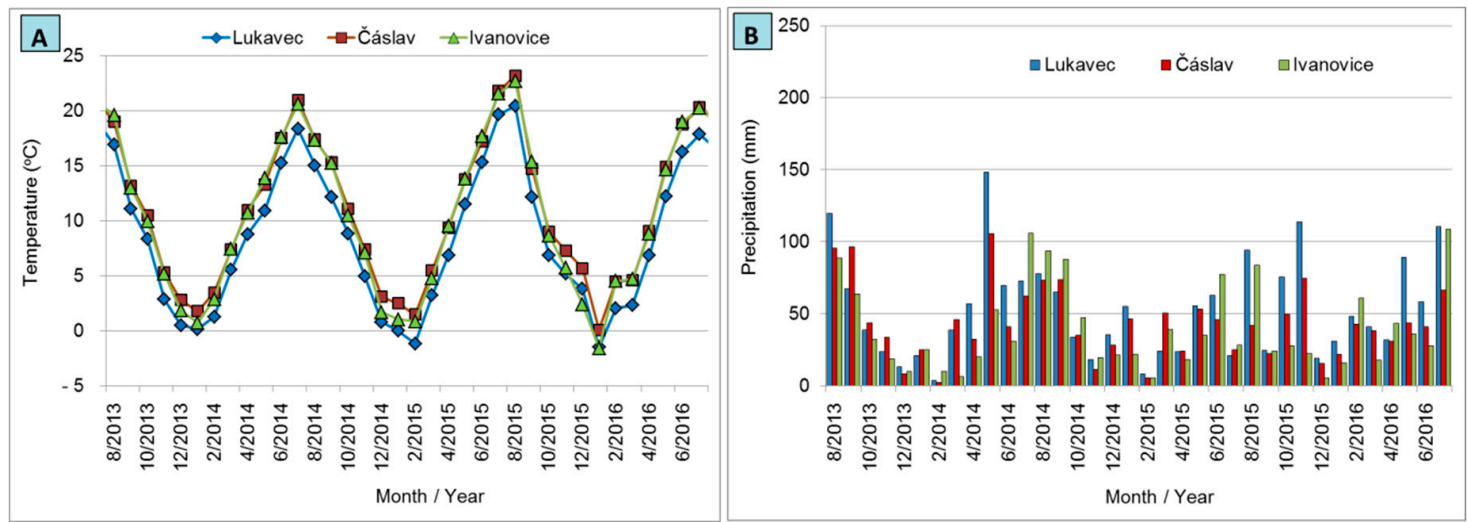

Figure 2. Monthly average temperature (A) and total precipitation (B) at the experimental locations (Lukavec, Čáslav, and Ivanovice) during 2013-2016.

\subsection{Experimental Design and Details}

The study was conducted during the years 2014-2016, where three contrasting treatments were examined: With no fertilization (N0; treatment no. 21 of the LCRE), with mineral fertilization (MIN; treatment 14), and organic fertilization (ORG; treatment 11) (Table 1). We selected winter wheat (Triticum aestivum L.) for the study. An eight-year crop rotation was carried out on four adjacent fields with four replications (blocks A-D): (1) Spring barley with clover, (2) clover, (3) winter wheat (the experimental year 2014), (4) maize for silage, (5) spring barley, (6) rapeseed, (7) winter wheat (the experimental years 2015 and 2016), and (8) potatoes. The LCRE was arranged in four blocks (A-D), each split into 12 experimental plots of $8 \times 8 \mathrm{~m}$. In each block, independent replicates of all 12 treatments were situated. 
Table 1. Average inputs of N, $\mathrm{P}$, and $\mathrm{K}$ in the mineral and organic fertilizers into the wheat and within the whole crop rotation.

\begin{tabular}{|c|c|c|c|c|}
\hline $\begin{array}{c}\text { Treatment } \\
\text { (LCRE Number) }\end{array}$ & Crop/Rotation & $\frac{N}{\left(k^{\prime} h^{-1} \text { year }^{-1}\right)}$ & $\begin{array}{c}P \\
\left(\mathrm{~kg} \mathrm{ha}^{-1} \text { year }^{-1}\right)\end{array}$ & $\begin{array}{c}\mathrm{K} \\
\left(\mathrm{kg} \mathrm{ha}^{-1} \text { year }^{-1}\right)\end{array}$ \\
\hline \multicolumn{5}{|l|}{ Zero (21) } \\
\hline N0 & Wheat & 0 & 0 & 0 \\
\hline \multicolumn{5}{|l|}{ Mineral (14) } \\
\hline \multirow[t]{2}{*}{ MIN } & Wheat & 85 & 41 & 88 \\
\hline & Whole rotation & 86 & 50 & 117 \\
\hline \multicolumn{5}{|l|}{ Organic (11) } \\
\hline \multirow[t]{2}{*}{ ORG } & Wheat & 8 & 4 & 12 \\
\hline & Whole rotation & 38 & 14 & 59 \\
\hline
\end{tabular}

The N, P, and K inputs from the ORG (Organic) treatment were calculated from the manure contents (40 $\mathrm{t} \mathrm{ha}^{-1}$ manure for potatoes and maize). LCRE, long-term crop rotation experiment.

\subsection{Root Studies}

Soil samples were taken in $10 \mathrm{~cm}$ segments using a hand-held corer (auger) that was $5.6 \mathrm{~cm}$ in diameter (Eiejkelkamp, Netherlands) to a depth of $120 \mathrm{~cm}$ or deeper, but at least $10 \mathrm{~cm}$ under the layer with roots. The roots were sampled within and between rows $(12.5 \mathrm{~cm}$ wide) at the grain-filling stage (BBCH 77-83) with four to six replications. The roots were washed with water on sieves, manually cleaned, and the root length was calculated according to [34]. The root density was calculated based on the root length and the volume of the soil sample and expressed in $\mathrm{cm} \mathrm{cm}^{-3}$; the total root length (TRL) in the $0-120 \mathrm{~cm}$ zone was calculated in $\mathrm{km} \mathrm{m}^{-2}$. As the root density under and between the rows was not significantly different below depths of 10 or $20 \mathrm{~cm}$, the average root data were analyzed. The root lengths (RLs) in $\mathrm{km} \mathrm{m}^{-2}$ are presented for the $0-30,30-60,60-90$, and $90-120 \mathrm{~cm}$ zones.

The maximum root depth was the depth of the $10 \mathrm{~cm}$ (bottom) layer, where the last of the roots occurred. The effective root depth (EfRD) was determined as the bottom of the soil layer, where the average root density decreased to under $2.0 \mathrm{~cm} \mathrm{~cm}^{-3}$.

\subsection{Statistical Analysis}

The effects of the factors (i.e., treatment, site, and season) on the root lengths and depths were analyzed using factorial analysis of variance (ANOVA) in Statistica 13 (Stat-Soft Inc., Tulsa, OK, USA, 2017). The Tukey's posthoc test was used to examine the differences between treatments, sites, and seasons at $p<0.05$. Pearson's correlation coefficient was calculated to determine the yield or precipitation and the TRL relationships.

\section{Results}

\subsection{Weather Conditions}

The weather conditions during the experimental years corresponded to the long-term characteristics of the experimental sites. Lukavec had a lower temperature, while Čáslav and Ivanovice had similar temperatures (on average, 2.1 and $2.3{ }^{\circ} \mathrm{C}$ higher than Lukavec); these were observed to agree with the altitudes of the sites (Table A1). The variability of the monthly precipitation was large, but a higher total at Lukavec was obvious. On average, the monthly precipitation (from October 2013 to July 2016) was higher by 8.5 and $12.5 \mathrm{~mm}$ at Lukavec compared to Čáslav and Ivanovice, respectively. In 2015, Lukavec was significantly drier during the January-June period (229 mm compared to 300 and $338 \mathrm{~mm}$ at Čáslav and Ivanovice, respectively); at Čáslav and Ivanovice, the total precipitation during this period was similar between these sites (Figure 2). 


\subsection{Effect of the Fertilization on the Total Root Length and Root Depth}

The long-term application of different fertilization systems, the site, and the year had significant effects on the total root length (TRL) in the $120 \mathrm{~cm}$ zone $(p<0.001)$ and the root length (RL) in all soil layers, namely, $0-30,30-60,60-90$, and $90-120 \mathrm{~cm}(p<0.0014)$ (Table 2). The average TRL per square meter of the sites reached 40.2, 44.9, and $52.2 \mathrm{~km}$ in the N0, ORG, and MIN treatments, respectively. The root lengths in the soil layers were significantly higher with the MIN treatment in comparison to both the N0 and ORG treatments. In the ORG treatment, the RL values were higher compared to those from the N0 treatment; however, the difference was mostly insignificant at $p<0.05$ (Table 3).

Table 2. Statistical analysis of the effects of the site (Čáslav, Ivanovice, and Lukavec), year (2014, 2015, and 2016), and treatment (N0, MIN, and ORG) factors on the root lengths (RLs) and the maximum and effective depths using analysis of variance (ANOVA).

\begin{tabular}{|c|c|c|c|c|c|c|c|}
\hline Factor & $\begin{array}{c}\text { RL } \\
0-30 \mathrm{~cm}\end{array}$ & $\begin{array}{c}\text { RL } \\
30-60 \mathrm{~cm}\end{array}$ & $\begin{array}{c}\text { RL } \\
60-90 \mathrm{~cm}\end{array}$ & $\begin{array}{c}\text { RL } \\
90-120 \mathrm{~cm}\end{array}$ & $\begin{array}{l}\text { Total RL } \\
0-120 \mathrm{~cm}\end{array}$ & $\begin{array}{l}\text { Maximum } \\
\text { Root Depth }\end{array}$ & $\begin{array}{c}\text { Effective } \\
\text { Root Depth }\end{array}$ \\
\hline Site & $*$ & $* * *$ & $* * *$ & $* * *$ & $* * *$ & $* * *$ & $* * *$ \\
\hline Year & $* * *$ & NS & NS & NS & $* * *$ & NS & $*$ \\
\hline Treatment & $* *$ & $* *$ & $* * *$ & $* * *$ & $* * *$ & $* * *$ & $*$ \\
\hline Site $\times$ Year & $* * *$ & $*$ & $*$ & NS & $* * *$ & NS & NS \\
\hline
\end{tabular}

$*, * *$, and ${ }^{* * *}$ denote significance at the $0.001,0.01$, and 0.05 levels, respectively; NS, not significant. The two- and the three-way interactions, except for site $\times$ year, were not significant $(p>0.14)$.

Table 3. Average wheat root lengths and depths for the three treatments, three sites, and three years, and the interaction of the site and the year.

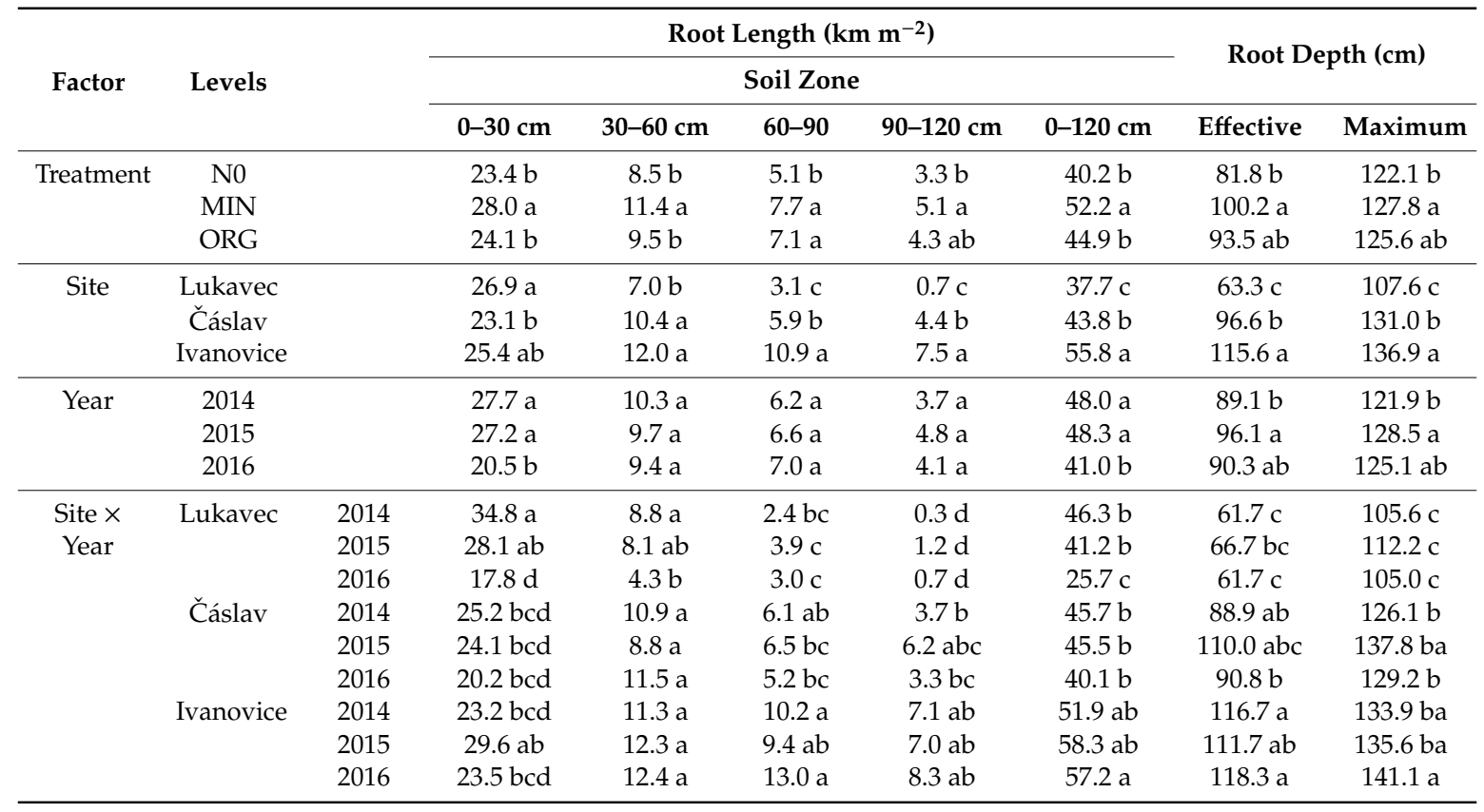

Mean values of the same factor or interaction for each root length or depth with the same letter were not significantly different at $p<0.05$. For the ANOVA, see Table 2. N0-zero fertilization, MIN-mineral fertilization, ORG-organic fertilization.

The effect of the treatments was similar at all the three sites. The average TRL per square meter was 30.2, 37.0, and $46.1 \mathrm{~km}$ for the N0, ORG, and MIN treatments, respectively, at Lukavec; 41.2, 42.4, and $47.7 \mathrm{~km}$, respectively, at Čáslav; 49.2, 55.3, and $62.9 \mathrm{~km}$, respectively, at Ivanovice (Table 3).

The effect of the fertilization on the effective root depth (EfRD) was also confirmed $(p<0.001)$, though the impact on the root maximum depth (RMD) was weaker $(p=0.033)$. Long-term MIN fertilization resulted in a significantly greater $(p=0.021)$ average EfRD of $102.2 \mathrm{~cm}$ in comparison 
to the N0 $(81.8 \mathrm{~cm})$ and ORG $(93.5 \mathrm{~cm})$ treatments. The average difference between the EfRDs after treatment with the N0 and optimal MIN fertilization reached 25.6, 20.8, and $8.9 \mathrm{~cm}$ at Lukavec, Čáslav, and Ivanovice, respectively.

\subsection{Effect of the Site}

The site conditions had a highly significant effect on the TRL and RL in the soil layers under $30 \mathrm{~cm}$ $(p<0.001)$; a weaker effect was found for the $0-30 \mathrm{~cm}$ layer $(p=0.019)$. The average values of the TRL at the Lukavec, Čáslav, and Ivanovice experimental sites were $37.7,43.8$, and $55.8 \mathrm{~km} \mathrm{~m}^{-2}$, respectively (in general agreement with the yield potential of the sites); the values of the TRL of the experimental sites were significantly different $(p<0.036)$. At Lukavec, a significantly lower RL (at $p<0.05)$ of the subsoil layers $(30-120 \mathrm{~cm}$ ) was found compared to the other sites; only the RL in the top 0-30 cm zone was similar to that at Čáslav and Ivanovice (Tables 2 and 3).

The site also had a significant effect on the maximum and effective root depths $(p<0.001)$ (Table 2). The differences in RMD and EfRD between all sites were significant (at $p<0.05$ ). The maximum and effective root depths were significantly lower $(107.6 \mathrm{~cm}$ and $66.3 \mathrm{~cm}$, respectively) at the Lukavec site, with its lighter soil and colder climate. This was compared to Čáslav and Ivanovice, where the RMD reached 131.0 and $136.9 \mathrm{~cm}$, respectively, and the EfRD was 96.6 and $115.6 \mathrm{~cm}$, respectively (Table 3).

\subsection{Effect of the Year}

The effect of the year was significant for the TRL and RL in the 0-30 cm topsoil layer $(p<0.001)$, as well as for the RMD, while the effect was not confirmed for the 30-60, 60-90, and 90-120 cm layers, nor for the EfRD $(p>0.16)$. In 2016, the topsoil root length was significantly lower than the RL in previous years at Lukavec and Časlav. The difference was especially prominent at Lukavec, where the RL in the 0-30 cm zone in 2016 was only 45\% of the RL in 2014. At Ivanovice, the RLs in 2014 and 2016 were lower than in 2015 (Table 3). The differences did not correlate with the precipitation during those years.

\subsection{Grain and Total Biomass Yields}

The average grain yields reached 7.3, 6.6, and $5.2 \mathrm{t} \mathrm{ha}^{-1}$ in Čáslav, Ivanovice, and Lukavec, respectively. The corresponding yields for the total aboveground biomass (grain + straw) were 13.5, 13.3, and $9.9 \mathrm{tha}^{-1}$, respectively (Table 4). The highest yields were reached in 2014 when the wheat was grown after clover.

Table 4. Grain and total biomass yields.

\begin{tabular}{cccccccccc}
\hline \multirow{2}{*}{ Treatment } & \multirow{2}{*}{ Year } & \multicolumn{3}{c}{ Grain Yield (t ha $\mathbf{~}^{-\mathbf{1}}$ ) } & \multicolumn{4}{c}{ Total Biomass $\left(\mathbf{t ~ h a ~}^{\mathbf{- 1}}\right)$} \\
\cline { 3 - 9 } & & Čáslav & Ivanovice & Lukavec & Average & Čáslav & Ivanovice & Lukavec & Average \\
\hline \multirow{2}{*}{ N0 } & 2014 & 7.9 & 6.7 & 7.0 & 7.2 & 13.4 & 14.2 & 13.7 & 13.7 \\
& 2015 & 6.6 & 3.8 & 2.1 & 4.2 & 13.2 & 7.0 & 4.0 & 8.1 \\
& 2016 & 5.9 & 4.5 & 2.5 & 4.3 & 10.7 & 9.1 & 4.4 & 8.1 \\
\hline \multirow{2}{*}{ MIN } & 2014 & 9.8 & 9.7 & 8.5 & 9.3 & 17.4 & 19.5 & 16.9 & 18.0 \\
& 2015 & 8.7 & 9.3 & 6.7 & 8.2 & 17.7 & 17.8 & 12.7 & 16.1 \\
& 2016 & 8.3 & 9.0 & 5.8 & 7.7 & 15.7 & 18.3 & 10.7 & 14.9 \\
\hline \multirow{2}{*}{ ORG } & 2014 & 7.0 & 7.2 & 8.0 & 7.4 & 12.4 & 15.2 & 15.8 & 14.5 \\
& 2015 & 5.9 & 4.3 & 2.9 & 4.4 & 11.7 & 8.4 & 5.2 & 8.4 \\
& 2016 & 5.3 & 5.0 & 2.9 & 4.4 & 9.7 & 9.8 & 5.3 & 8.3 \\
\hline \multirow{2}{*}{ Average } & 7.3 & 6.6 & 5.2 & 6.3 & 13.5 & 13.3 & 9.9 & 12.2 \\
\hline
\end{tabular}

N0-zero fertilization, MIN-mineral fertilization, ORG-organic fertilization. 


\section{Discussion}

\subsection{Effect of the Fertilization on the Total Root Length and Root Depth}

When averaging over the sites and years, the RMD only ranged between 122.1 and $127 \mathrm{~cm}$ for the different treatments (Table 3). Based upon an average of the years, the maximum root depth was reduced by only $5.6-5.8 \mathrm{~cm}$ in the N0 treatment compared to the MIN fertilization. This means that the long-term application of MIN fertilization stimulated root growth and increased the root density in the deep subsoil zone compared to the N0 treatment.

The stimulating effect of the fertilization on root lengths corresponded to the impacts of the treatments on the yields during the experimental years (the correlation coefficient ranged from +0.39 to +0.78$)$, mostly due to poorer root growth and lower yields from the N0 treatment, as well as lower yields and root growth at Lukavec, which was the site with lower productivity (Tables 4 and 5). The average wheat yields from the N0 treatment reached 55\%,76\%, and 54\% of the MIN treatment at Lukavec, Ćáslav, and Ivanovice, respectively, based upon an average over the years (Table 4). As expected, the spring $\mathrm{N}_{\min }$ content (before the first regenerative fertilization) was also lower after the N0 and ORG treatments in comparison to the MIN treatment (Figure A1). Hence, together with the N fertilization, the wheat crop in the MIN treatment grew under the conditions of significantly higher available nitrogen content in the soil.

Table 5. Correlation between the average grain and biomass yields and root length, maximum depth, and effective depth.

\begin{tabular}{|c|c|c|c|c|c|c|c|}
\hline \multirow{3}{*}{ Yield } & \multicolumn{4}{|c|}{ Root Length $\left(\mathrm{km} \mathrm{m}^{-2}\right)$} & \multicolumn{3}{|c|}{ Root Depth (cm) } \\
\hline & \multicolumn{2}{|c|}{ Soil Zone (cm) } & \multirow{2}{*}{$60-90$} & \multirow{2}{*}{ 90-120 } & \multirow{2}{*}{$0-120$} & \multirow{2}{*}{ Effective } & \multirow{2}{*}{ Maximum } \\
\hline & 0-30 & $30-60$ & & & & & \\
\hline Grain yield & 0.39 & 0.74 & 0.48 & 0.55 & 0.67 & 0.56 & 0.56 \\
\hline Biomass yield & 0.42 & 0.78 & 0.56 & 0.61 & 0.74 & 0.62 & 0.60 \\
\hline
\end{tabular}

Correlation coefficients in bold are significant at $p<0.05, N=10$.

The published data on the effects of increasing the soil $\mathrm{N}$ levels on the root density and root depth are not consistent. Both positive and negative reactions can be found due to differences in the plant and soil nutritional statuses, interactions with site conditions, etc. Significant positive effects have been reported; for example, [35] observed a positive effect of $\mathrm{N}$ fertilization on root density in the deep soil layers (except at the highest rate), while [36] found better development of the root system in the deeper soil layers, without nitrogen fertilization. In some experiments, $\mathrm{N}$ increased the wheat root density but reduced it at the highest rates [37]. In a field experiment in Ruzyně (with soil similar to that at the Ivanovice site), we observed a significant effect of increasing $\mathrm{N}$ rates on the winter wheat root depth (with a slight reduction at $200 \mathrm{~kg} \mathrm{~N} \mathrm{ha}^{-1}$ ). However, the apparent depletion of nitrogen from the subsoil was reduced at a high $\mathrm{N}$ rate $[27,38]$. Some authors have stressed the importance of an increase in the uptake rate per unit of root length in the deep soil layers with a low root density when the soil layers above cannot cover the plant's demands for $\mathrm{N}$ and other resources $[28,29,39]$.

The possible stimulating effect of a lowered nutrient supply on the root density and the root depth (as an adaptation to low source levels) that was observed by some authors [36,40] was not confirmed. This is surprising, as long-term low or no fertilization reduces yield, and consequently, the content of the elements in the crop biomass $[33,41]$, which indicates an increased crop demand for nutrients. It appears that more factors are interacting in the processes of root growth. Among others, it should be noted that the N0 treatment was not only without $\mathrm{N}$ but also without the other macro- and micronutrients supplied by mineral fertilizers and manure. For example, Chen et al. (2018) found that the richness of the bacterial community was reduced in both low- and high-nitrogen fertilizers compared to the control treatment, and increased in high-N fertilizers plus $\mathrm{P}$ or $\mathrm{K}$ treatments [42]. 
Under laboratory conditions, the various effects of $\mathrm{P}$ and $\mathrm{K}$ deficiencies on root traits (both stimulating and reducing) have been reported [43-45].

The water content in early spring only showed negligible differences between the treatments; thus, the possible modification of root growth during the early spring growth period was not likely. However, fertilized wheat depleted the soil water reserves in the subsoil slightly more, which was apparent from the soil moisture profiles at harvest in this and other experiments. Greater water depletion in fertilized wheat crops (with higher biomass and leaf area) occurs during the main growth period; thus, the stimulation of greater root growth as an adaptive trait cannot be excluded $[30,46]$.

\subsection{The Effect of the Site and Experimental Year}

The effect of the year was significant for TRL and RL only in the 0-30 cm topsoil zone. The differences in TRL between years did not correlate with the precipitation during those years; thus, other factors (possibly precipitation distribution, soil water, and available $\mathrm{N}$ during growth) must have been responsible. The results only correspond to the fact that the interaction of the year and site had significant impacts on all root traits $(p<0.05)$, except for EfRL $(p=0.077)$ (Table 2$)$. Extreme weather events, such as low or high temperatures with severe drought or soil flooding, have been reported to affect the root system [47], but no such specific conditions occurred during the experimental years.

Root growth and depth may be affected by the distribution of water and nutrients, especially nitrogen, within the soil profile. Several authors have described the proliferation of roots in zones with favorable conditions; however, no convincing data on root depth are available from long-term experiments. The clover pre-crop grown in 2013 might have improved conditions for wheat growth and yields in 2014 compared to the oilseed rape pre-crop grown in 2014 and 2015. However, the clover pre-crop increased the $\mathrm{N}_{\min }$ content during spring 2014 only at Lukavec, not at the other two sites (Figure A1). The better yields in 2014 (Table 4) were probably also the result of higher precipitation in comparison to the dry years of 2015 and 2016 (Figure 2). It should be noted that the better N supply, due to fertilization or higher $\mathrm{N}_{\text {min }}$ content, enhanced the yields more markedly at Lukavec than at Ivanovice and Čáslav, which were the sites with higher natural productivity $[7,10,24]$. The $\mathrm{N}_{\text {min }}$ (mostly in nitrate form) in the MIN treatment shifted downward during winter 2014/2015 and 2015/2016 and accumulated in the shallow $30-50 \mathrm{~cm}$ subsoil of Čáslav and Ivanovice (Figure A1), but was probably leached into the layers below $50 \mathrm{~cm}$ at Lukavec.

\subsection{Root Length Density Distribution}

The root length density of wheat decreased with depth in this experiment, similar to that which occurs in other crops [28,48-50].

The effects of the site conditions were apparent in the distribution of root lengths in the soil profile (Figure 3). The greater proportion of RL in the topsoil $(0-30 \mathrm{~cm})$ at Lukavec $(71 \%$ of the TRL), in comparison to Čáslav (53\%) and Ivanovice (46\%), suggests that wheat plants under the worse soil conditions concentrated their roots in the enriched arable layer. The differences in root distributions show that $90 \%$ of the total root lengths were found in the soil zone down to 60,93 , and $98 \mathrm{~cm}$ at Lukavec, Ćáslav, and Ivanovice, respectively. A higher root density in the top 0-30 cm enables the quick depletion of nutrients that are prone to leaching, and a high density is important for the uptake of less-mobile ions, such as phosphorus or ammonium nitrogen. Deeper roots are effective for the depletion of source reserves in deep soils with a high water capacity, less precipitation, and relatively slow leaching of nutrients out of the root zone. For example, according to [39], higher wheat yields were related to higher root colonization of the deeper soil layers under rain-fed conditions and sub-optimal fertilization, in contrast with irrigated crops. Data on factors modifying the root depth may improve the calculation of the available water supply, as well as predictions of the possible onset of water shortages under various weather conditions [21]. 


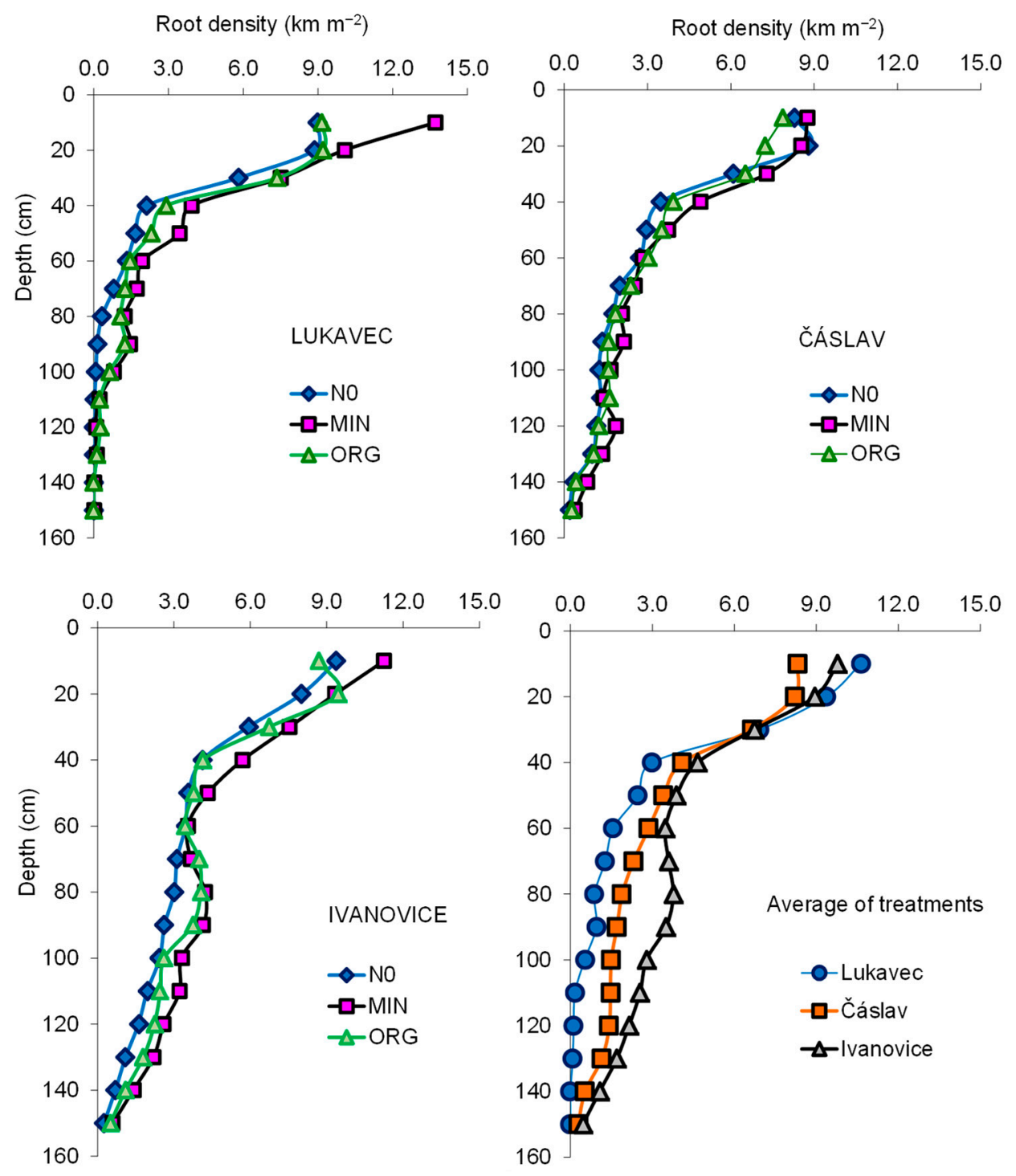

Figure 3. Average distribution of root density in the soil profile of the N0, MIN, and ORG treatments at the Lukavec, Ćáslav, and Ivanovice sites. The average of the N0, MIN, and ORG treatments at the experimental sites is shown in the bottom right. N0-zero fertilization, MIN-mineral fertilization, ORG-organic fertilization.

The effects of both poorer soil quality (lower humus and nutrient content, lower water capacity, fluctuating soil moisture, and a higher proportion of stones (Table A1), as well as a smaller supply of available water and nutrients in the Lukavec subsoil, contributed to poorer root growth when compared to the other sites. Müller (2004) proposed that a higher clay content functions as a "lubricant" for root growth, while a high content of sharp sand particles can damage root tissues [51]. As a further example, a higher number or better stability of biopores after pre-crop roots, or earthworms and other soil organisms in medium and heavy soils (observed mainly at Čáslav), may contribute to root growth and penetration into the deep soil layers [52]. On the other hand, heavy soils are more prone to soil compaction and the restriction of root growth.

The wheat root length and depth data found in the literature differ greatly, which is not surprising considering the immense range of production, soil, and climate conditions under which wheat is grown, and that is not even considering their diverse genetic pedigrees. Wheat root lengths from approximately 4-86 $\mathrm{km} \mathrm{m}^{-2}$ are described in the literature [53-55]. Our root data rank among the higher published data. Besides the site and experimental conditions, methods of root sampling and separation affect the observed root length [56]. Similarly, wheat root depth ranges from 60 to more 
than $200 \mathrm{~cm}[21,45,57]$. To the best of our knowledge, there have been few examinations of the whole root zone data in long-term fertilization experiments. Ericson et al. (2000) observed better barley root growth in a lay-dominated system, in contrast to annual crop-dominated systems [58]. A long-term lay-dominated system improved both the porosity and organic carbon, as well as lessened the soil volume weight, which was in agreement with higher yields.

\subsection{Potential for the Depletion of Water and Leached Nutrients from Deep Subsoil Layers}

The modification of the root depth and root density distribution using fertilization and site conditions may have significant consequences for the depletion of water reserves and leached nutrients from the subsoil $[21,27,28,30,31]$, and thus, the balance of $\mathrm{N}$ and other nutrients may be affected. Nutrient balance is an important trait for the evaluation of the sustainability of various crop systems. A negative balance of nutrients indicates the exploitation of soil reserves and a possible worsening of soil fertility, along with other traits. In contrast, a high surplus (especially of nitrogen) suggests losses to the environment or increasing soil reserves. Furthermore, data on root depth and the possible utilization of the deep soil supply from the previous year(s) may contribute to the explanation of the differences in yield and nutrient uptake among treatments, sites, and years. For example, in a long-term experiment, Nemeth (1996) described the maximum mineral $\mathrm{N}$ content in the 1.5-2.5 m zone in treatments with a surplus of $\mathrm{N}$, and as the result of lower $\mathrm{N}$ uptake due to drought [59].

Lukavec's soil and climate conditions (Table A1) and the effect of the treatment on the root density and depth suggest a greater risk of unused nitrate $\mathrm{N}$ leaching under the root zone in comparison to deep soils, with their greater water capacity and better root growth [13]. Káš et al. (2019) found higher wheat yields in those years that had higher precipitation at Lukavec in comparison to Ivanovice; this was found in the long-term International Organic Nitrogen Long-term Fertilization Experiment (IOSDV) [7], which suggested complex interactions between water supply effects and leaching, growth, and nutrient depletion or demand.

\section{Conclusions}

The 60-year duration of contrast fertilization systems has mostly had a statistically significant effect on root density in the arable and subsoil zones, as well as on the effective root depth. However, despite the greatly different inputs of fertilizers, and based on yearly averages, the maximum root depth was only reduced by $5.6-5.8 \mathrm{~cm}$ in the experimental sites with N0 treatments compared to MIN fertilization. The effective root depth was reduced in the N0 treatment by $8.9-25.6 \mathrm{~cm}$ in comparison to the MIN treatment at the experimental sites. The plots with an N0 treatment showed no signs of an adaptive reaction of the root system, improving the potential for nutrient acquisition, while MIN fertilization contributed to the potential for effective utilization of resources from the soil profile. These results suggest that wheat crops have a high potential for the depletion of nutrients and water from deep soil zones thanks to their deep roots. This data contributes to a reliable interpretation of the nutrient balance in long-term experiments.

Author Contributions: Design of the study, methodology, and sampling, P.S. and J.H.; root separation, cleaning, and counting, P.S. and I.R.; statistical analysis, J.H. and G.K.; LTE management, E.K.; interpretation and discussion, P.S. and J.H.; writing and editing, J.H., I.R. and G.K.; funding acquisition, J.H. All authors have read and agreed to the published version of the manuscript.

Funding: This study was supported by the Ministry of Agriculture of the Czech Republic, institutional support MZE-RO0418.

Acknowledgments: The authors wish to thank Verra Schaferlingová and Lada Kozlovská for their technical support. They also thank the three anonymous reviewers who helped to increase the clarity of the paper with their comments.

Conflicts of Interest: The authors declare they have no conflicts of interest. 


\section{Appendix A}

Table A1. Basic conditions of the experimental sites.

\begin{tabular}{|c|c|c|c|c|}
\hline \multirow{2}{*}{ Site Characteristics } & \multirow{2}{*}{ Unit } & \multicolumn{3}{|c|}{ Site } \\
\hline & & Čáslav & Ivanovice & Lukavec \\
\hline \multirow{2}{*}{ Geographic coordinates } & \multirow[b]{3}{*}{ m a.s.l. } & $49^{\circ} 53^{\prime} 29^{\prime \prime} \mathrm{N}$ & $49^{\circ} 18^{\prime} 40^{\prime \prime} \mathrm{N}$ & $49^{\circ} 33^{\prime} 23^{\prime \prime} \mathrm{N}$ \\
\hline & & $15^{\circ} 23^{\prime} 38^{\prime \prime} \mathrm{E}$ & $17^{\circ} 05^{\prime} 45^{\prime \prime} \mathrm{E}$ & $14^{\circ} 58^{\prime} 39^{\prime \prime} \mathrm{E}$ \\
\hline Altitude & & 263 & 225 & 620 \\
\hline $\begin{array}{l}\text { Long-term average } \\
\text { temperature }\end{array}$ & ${ }^{\circ} \mathrm{C}$ & 8.9 & 8.4 & 6.8 \\
\hline $\begin{array}{l}\text { Long-term average } \\
\text { precipitation }\end{array}$ & $\mathrm{mm}$ & 555 & 556 & 686 \\
\hline $\begin{array}{l}1956 \text { analysis (contrast } \\
\text { treatments) Available P } \\
\text { (Egner), K, and Mg } \\
\text { (Schachtschabel) }\end{array}$ & $\mathrm{mg} \mathrm{kg}^{-1}$ soil & $\begin{array}{l}\text { 30, } 108, \text { and } 114, \\
\text { respectively }\end{array}$ & $\begin{array}{l}25,138, \text { and } 111, \\
\text { respectively }\end{array}$ & $\begin{array}{l}21,276 \text {, and } 152, \\
\text { respectively }\end{array}$ \\
\hline $\begin{array}{c}2016 \text { analysis } \\
\text { (contrast treatments) }\end{array}$ & \multirow{5}{*}{$\begin{array}{c}- \\
\mathrm{mg} \mathrm{kg}^{-1} \text { soil } \\
\mathrm{mg} \mathrm{kg}^{-1} \text { soil } \\
\mathrm{g} \mathrm{kg}^{-1} \text { soil }\end{array}$} & & \multirow{5}{*}{$\begin{array}{c}7.02-7.13 \\
33-120 \\
108-197 \\
3.4-4.8\end{array}$} & \multirow{5}{*}{$\begin{array}{c}5.51-5.64 \\
46-151 \\
127-159 \\
1.9-2.2\end{array}$} \\
\hline $\mathrm{pH} / \mathrm{KCl}$ & & $6.56-6.71$ & & \\
\hline Available P (Mehlich 3) & & $37-145$ & & \\
\hline Available K (Mehlich 3) & & $88-161$ & & \\
\hline Available Ca (Mehlich 3) & & $2.6-2.8$ & & \\
\hline $\mathrm{C}_{\text {org }}$ & \multirow{2}{*}{$\begin{array}{l}\% \\
\% \\
\end{array}$} & 1.46 & \multirow{2}{*}{$\begin{array}{l}1.80 \\
0.21\end{array}$} & \multirow{2}{*}{$\begin{array}{l}1.37 \\
0.14\end{array}$} \\
\hline $\mathrm{N}_{\text {total }}$ & & 0.14 & & \\
\hline $\begin{array}{c}\text { Soil type } \\
\text { Texture } \\
\text { Topsoil }(0-30 \mathrm{~cm}) \\
\text { Subsoil }(30-70 \mathrm{~cm}) \\
\text { Deep subsoil }(70-130 \mathrm{~cm})\end{array}$ & & $\begin{array}{c}\text { Greyic Phaeozem } \\
\text { on loess } \\
\text { Silt loam } \\
\text { Silt } \\
\text { Silt }\end{array}$ & $\begin{array}{l}\text { Degraded } \\
\text { Chernozem } \\
\text { on loess } \\
\text { Loam } \\
\text { Silt } \\
\text { Silt }\end{array}$ & $\begin{array}{l}\text { Cambisol } \\
\text { (brown soil) } \\
\text { Sandy loam } \\
\text { Sandy loam } \\
\text { Sandy loam }\end{array}$ \\
\hline Field water capacity & \multirow{4}{*}{ vol. $\%$} & & & \\
\hline Topsoil $(0-30 \mathrm{~cm})$ & & 29.6 & 30.3 & 21.8 \\
\hline Subsoil $(30-70 \mathrm{~cm})$ & & 31.4 & 31.3 & 20.6 \\
\hline Deep subsoil $(70-130 \mathrm{~cm})$ & & 32.1 & 30.8 & 18.5 \\
\hline
\end{tabular}

Note: Total nitrogen and carbon contents in the topsoil $(0-30 \mathrm{~cm})$ of the mineral treatment (treatment 14 of the LCRE) are shown. 
Lukavec

Čáslav

Ivanovice

$\mathrm{N}_{\text {min }}\left(\mathrm{kg} \mathrm{ha}^{-1}\right)$

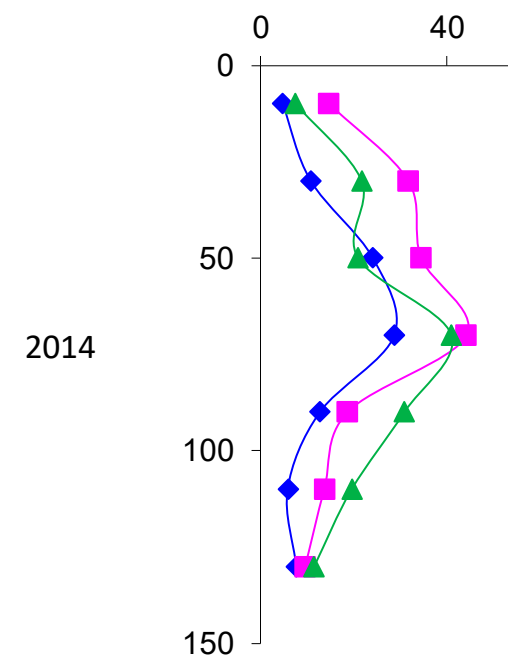

800

40

$80 \quad 0$

40

80
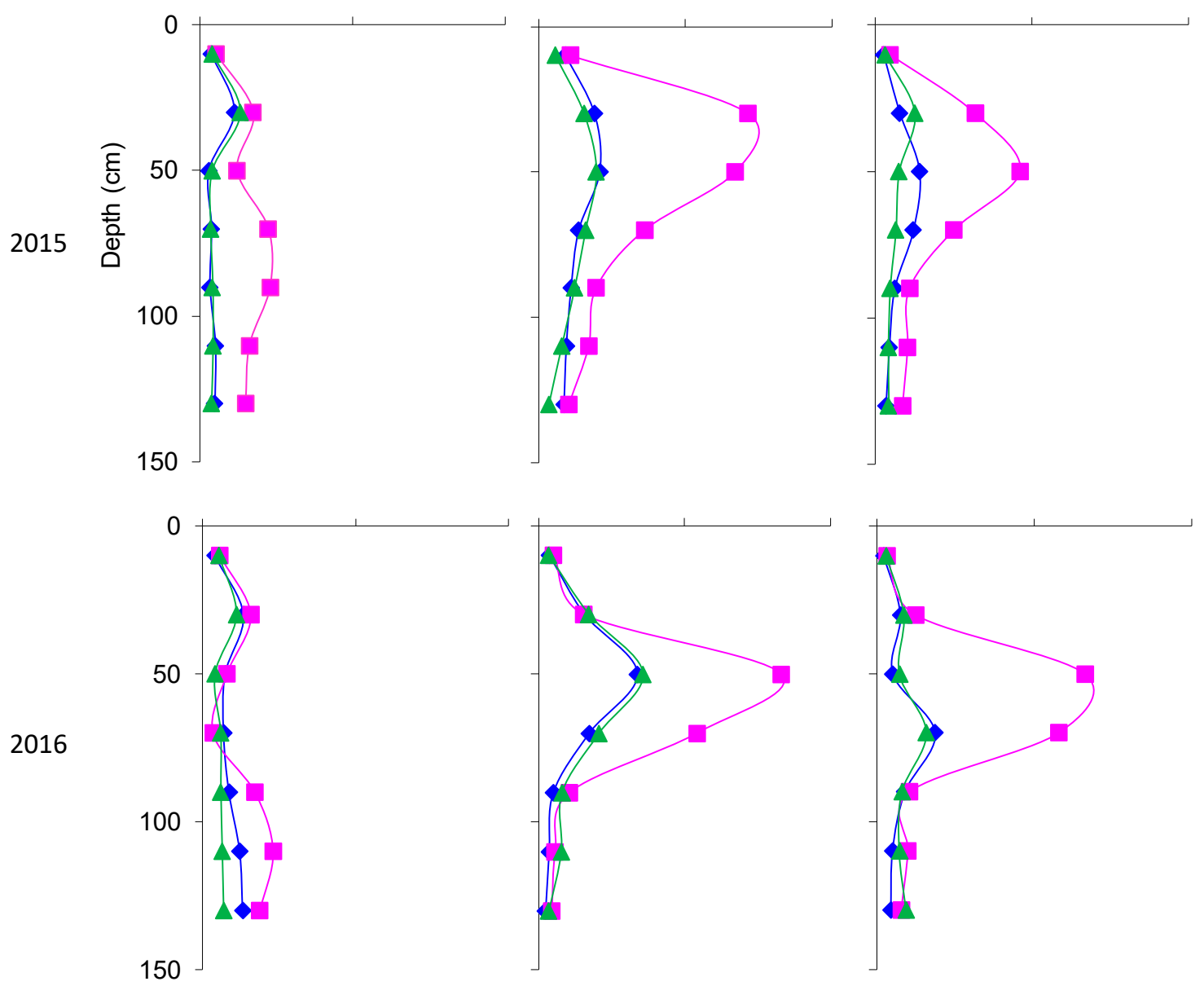

Figure A1. Distribution of the mineral nitrogen content $\left(\mathrm{N}_{\min }\right)$ in soil layers 0-10, 10-30, 30-50, 50-70, $70-90,90-110$, and $110-130 \mathrm{~cm}$ in early spring at the start of plant regeneration.

\section{References}

1. Johnston, A.E.; Poulton, P.R. The importance of long-term experiments in agriculture: Their management to ensure continued crop production and soil fertility; the Rothamsted experience. Eur. J. Soil Sci. 2018, 69, 113-125. [CrossRef] 
2. Körschens, M.; Albert, E.; Armbruster, M.; Barkusky, D.; Baumecker, M.; Behle-Schalk, L.; Bischoff, R.; Čergan, Z.; Ellmer, F.; Herbst, F.; et al. Effect of mineral and organic fertilization on crop yield, nitrogen uptake, carbon and nitrogen balances, as well as soil organic carbon content and dynamics: Results from 20 European long-term field experiments of the twenty-first century. Arch. Agron. Soil Sci. 2013, 59, 1017-1040. [CrossRef]

3. Rasmussen, P.E.; Goulding, K.W.T.; Brown, J.R.; Grace, P.R.; Janzen, H.H.; Korschens, M. Long-Term Agroecosystem Experiments: Assessing Agricultural Sustainability and Global Change. Science 1998, 282, 893-896. [CrossRef]

4. Macdonald, A.J.; Poulton, P.R.; Glendining, M.J.; Goulding, K.W.T.; Perryman, S.A.M.; Powlson, D.S. Sustainable intensification-lessons from the Rothamsted long-term experiments. Asp. Appl. Biol. Sustain. Intensif. 2017, 136, 239-244.

5. Merbach, W.; Deubel, A. The Long-Term Fertilization Trials in Halle (Saale), Germany. A Tool for Sustainable and Environmentally Compatible Land Management-Contributions of Plant Nutrition Science in Halle 13; Springer: Berlin/Heidelberg, Germany, 2007. [CrossRef]

6. Balík, J.; Černý, J.; Kulhánek, M.; Sedlář, O. Soil carbon transformation in long-term field experiments with different fertilization treatments. Plant Soil Environ. 2018, 64, 578-586. [CrossRef]

7. Káš, M.; Mühlbachova, G.; Kusá, H. Winter wheat yields under different soil-climatic conditions in a long-term field trial. Plant Soil Environ. 2019, 65, 27-34. [CrossRef]

8. Kunzová, E.; Hejcman, M. Yield development of winter wheat over 50 years of FYM, N, P and K fertilizer application on black earth soil in the Czech Republic. Field Crop. Res. 2009, 111, 226-234. [CrossRef]

9. Kunzová, E.; Hejcman, M. Yield development of winter wheat over 50 years of nitrogen, phosphorus and potassium application on greyic Phaeozem in the Czech Republic. Eur. J. Agron. 2010, 33, 166-174. [CrossRef]

10. Madaras, M.; Mayerová, M.; Kumhálová, J.; Lipavský, J. The influence of mineral fertilisers, farmyard manure, liming and sowing rate on winter wheat grain yields. Plant Soil Environ. 2018, 64, 38-46. [CrossRef]

11. Karimi, R.; Janzen, H.; Smith, E.G.; Ellert, B.; Kröbel, R. Nitrogen balance in century-old wheat experiments. Can. J. Soil Sci. 2017, 97, 580-591. [CrossRef]

12. Zhou, Z.; Palmborg, C.; Ericson, L.; Dryler, K.; Lindgren, K.; Bergkvist, G.; Parsons, D. A 60-years old field experiment demonstrates the benefit of leys in the crop rotation. Acta Agric. Scand. Sect. B Plant Soil Sci. 2018, 69, 1-7. [CrossRef]

13. Haberle, J.; Káš, M. Simulation of nitrogen leaching and nitrate concentration in a long-term field experiment. J. Cent. Eur. Agric. 2012, 13, 416-425. [CrossRef]

14. Németh, T. Nitrogen in Hungarian soils-Nitrogen management relation to groundwater protection. J. Contam. Hydrol. 1995, 20, 185-208. [CrossRef]

15. Kunzová, E. The effect of crop rotation and fertilization on dry matter yields and organic $C$ content in soil in long-term field experiments in Prague. Arch. Agron. Soil Sci. 2013, 59, 1177-1191. [CrossRef]

16. Schmidt, L.; Warnstorff, K.; Dörfel, H.; Leinweber, P.; Lange, H.; Merbach, W. The influence of fertilization and rotation on soil organic matter and plant yields in the long-termEternal Rye trial in Halle (Saale), Germany. J. Plant Nutr. Soil Sci. 2000, 163, 639-648. [CrossRef]

17. Sosulski, T.; Szara, E.; Stepien, W.; Szymańska, M. Nitrous oxide emissions from the soil under different fertilization systems on a long-term experiment. Plant Soil Environ. 2014, 60, 481-486. [CrossRef]

18. Comas, L.H.; Becker, S.; Cruz, V.V.; Byrne, P.F.; Dierig, D.A. Root traits contributing to plant productivity under drought. Front. Plant Sci. 2013, 4, 442. [CrossRef]

19. Gao, W.; Hodgkinson, L.; Jin, K.; Watts, C.W.; Ashton, R.; Shen, J.; Ren, T.; Dodd, I.; Binley, A.; Phillips, A.L.; et al. Deep roots and soil structure. Plant Cell Environ. 2016, 39, 1662-1668. [CrossRef] [PubMed]

20. Wasaya, A.; Zhang, X.; Fang, Q.; Yan, Z. Root Phenotyping for Drought Tolerance: A Review. Agronomy 2018, 8, 241. [CrossRef]

21. Haberle, J.; Svoboda, P. Calculation of available water supply in crop root zone and the water balance of crops. Contrib. Geophys. Geodesy 2015, 45, 285-298. [CrossRef]

22. Hoad, S.P.; Russell, G.; Kettlewell, P.S.; Belshaw, M. Root System Management in Winter Wheat: Practices to Increase Water and Nitrogen Use. Home Grown Cereals Authority (HGCA). Project Report No. 2014. Available online: https://ahdb.org.uk/root-system-management-in-winter-wheat-practices-to-increasewater-and-nitrogen-use (accessed on 30 June 2020). 
23. Balík, J.; Černý, J.; Kulhánek, M.; Sedlář, O.; Suran, P. Balance of potassium in two long-term field experiments with different fertilization treatments. Plant Soil Environ. 2019, 65, 225-232. [CrossRef]

24. Buráňová, Š.; Černý, J.; Kulhánek, M.; Vašák, F.; Balík, J. Influence of mineral and organic fertilizers on yield and nitrogen efficiency of winter wheat. Int. J. Plant Prod. 2015, 9, 257-272.

25. Constantin, J.; Mary, B.; Laurent, F.; Aubrion, G.; Fontaine, A.; Kerveillant, P.; Beaudoin, N. Effects of catch crops, no till and reduced nitrogen fertilization on nitrogen leaching and balance in three long-term experiments. Agric. Ecosyst. Environ. 2010, 135, 268-278. [CrossRef]

26. Öborn, I.; Edwards, A.C.; Witter, E.; Oenema, O.; Ivarsson, K.; Withers, P.J.A.; Nilsson, S.; Stinzing, A.R. Element balances as a tool for sustainable nutrient management: A critical appraisal of their merits and limitations within an agronomic and environmental context. Eur. J. Agron. 2003, 20, 211-225. [CrossRef]

27. Haberle, J.; Svoboda, P.; Krejcova, J. Uptake of mineral nitrogen from subsoil by winter wheat. Plant Soil Environ. 2011, 52, 377-384. [CrossRef]

28. Kautz, T.; Amelung, W.; Ewert, F.; Gaiser, T.; Horn, R.; Jahn, R.; Javaux, M.; Kemna, A.; Kuzyakov, Y.; Munch, J.; et al. Nutrient acquisition from arable subsoils in temperate climates: A review. Soil Boil. Biochem. 2013, 57, 1003-1022. [CrossRef]

29. Kuhlman, H.; Barraclough, P.B.; Weir, A.H. Utilization of mineral nitrogen in the subsoil by winter wheat. Z. Pflanzenernahr. Bodenkd. 1989, 152, 291-295. [CrossRef]

30. Thorup-Kristensen, K.; Halberg, N.; Nicolaisen, M.; Olesen, J.E.; Crews, T.E.; Hinsinger, P.; Kirkegaard, J.; Pierret, A.; Dresbøll, D.B. Digging Deeper for Agricultural Resources, the Value of Deep Rooting. Trends Plant Sci. 2020, 25, 406-417. [CrossRef]

31. Thorup-Kristensen, K.; Salmerón Cortasa, M.S.; Loges, R. Winter wheat roots grow twice as deep as spring wheat roots, is this important for N uptake and N leaching losses? Plant Soil 2009, 322, 101-114. [CrossRef]

32. Holík, L.; Hlisnikovský, L.; Kunzová, E. The effect of mineral fertilizers and farmyard manure on winter wheat grain yield and grain quality. Plant Soil Environ. 2018, 64, 491-497. [CrossRef]

33. Hejcman, M.; Kunzová, E. Sustainability of winter wheat production on sandy-loamy Cambisol in the Czech Republic: Results from a long-term fertilizer and crop rotation experiment. Field Crop. Res. 2010, 115, 191-199. [CrossRef]

34. Tennant, D. A Test of a Modified Line Intersect Method of Estimating Root Length. J. Ecol. 1975, 63, 995. [CrossRef]

35. Liu, W.; Ma, G.; Wang, C.; Wang, J.; Lu, H.; Li, S.; Feng, W.; Xie, Y.; Ma, D.; Kang, G. Irrigation and Nitrogen Regimes Promote the Use of Soil Water and Nitrate Nitrogen from Deep Soil Layers by Regulating Root Growth in Wheat. Front. Plant Sci. 2018, 9, 32. [CrossRef] [PubMed]

36. De Giorgio, D.; Fornaro, F. Nitrogen fertilization and root growth dynamics of durum wheat for a sustainable production. Ital. J. Agron. 2012, 7, e29. [CrossRef]

37. Rasmussen, I.S.; Dresbøll, D.B.; Thorup-Kristensen, K. Winter wheat cultivars and nitrogen (N) fertilization-Effects on root growth, $\mathrm{N}$ uptake efficiency and $\mathrm{N}$ use efficiency. Eur. J. Agron. 2015, 68, 38-49. [CrossRef]

38. Svoboda, P.; Haberle, J. The effect of nitrogen fertilization on root distribution of winter wheat. Plant Soil Environ. 2011, 52, 308-313. [CrossRef]

39. Postic, F.; Beauchêne, K.; Gouache, D.; Doussan, C. Scanner-Based Minirhizotrons Help to Highlight Relations between Deep Roots and Yield in Various Wheat Cultivars under Combined Water and Nitrogen Deficit Conditions. Agronomy 2019, 9, 297. [CrossRef]

40. Duque, L.O.; Villordon, A. Root Branching and Nutrient Efficiency: Status and Way Forward in Root and Tuber Crops. Front. Plant Sci. 2019, 10, 237. [CrossRef]

41. Tlustoš, P.; Hejcman, M.; Kunzová, E.; Hlisnikovský, L.; Zámečníková, H.; Száková, J. Nutrient status of soil and winter wheat (Triticum aestivum L.) in response to long-term farmyard manure application under different climatic and soil physicochemical conditions in the Czech Republic. Arch. Agron. Soil Sci. 2017, 64, 70-83. [CrossRef]

42. Chen, Y.L.; Liu, J.T.; Liu, S.T. Effect of long-term mineral fertilizer application on soil enzyme activities and bacterial community composition. Plant Soil Environ. 2018, 64, 571-577. [CrossRef]

43. McLachlan, J.W.; Haling, R.E.; Flavel, R.J.; Guppy, C.N.; Simpson, R.J.; Haling, R.E. Root proliferation in response to $\mathrm{P}$ stress and space: Implications for the study of root acclimation to low $\mathrm{P}$ supply and $\mathrm{P}$ acquisition efficiency. Plant Soil 2020, 452, 1-16. [CrossRef] 
44. Nguyen, V.L.; Stangoulis, J. Variation in root system architecture and morphology of two wheat genotypes is a predictor of their tolerance to phosphorus deficiency. Acta Physiol. Plant. 2019, 41, 109. [CrossRef]

45. Roshani, G.; Narayanasamy, G. Effects of potassium on temporal growth of root and shoot of wheat and its uptake in different soils. Int. J. Plant Prod. 2010, 4, 25-32.

46. Friedli, C.N.; Abiven, S.; Fossati, D.; Hund, A. Modern wheat semi-dwarfs root deep on demand: Response of rooting depth to drought in a set of Swiss era wheats covering 100 years of breeding. Euphytica 2019, 215, 85. [CrossRef]

47. Zhou, G.; Zhou, X.; Nie, Y.; Bai, S.H.; Zhou, L.; Shao, J.; Cheng, W.; Wang, J.; Hu, F.; Fu, Y. Drought-induced changes in root biomass largely result from altered root morphological traits: Evidence from a synthesis of global field trials. Plant Cell Environ. 2018, 41, 2589-2599. [CrossRef]

48. Fan, J.; McConkey, B.; Wang, H.; Janzen, H. Root distribution by depth for temperate agricultural crops. Field Crop. Res. 2016, 189, 68-74. [CrossRef]

49. Haberle, J.; Svoboda, P. Impacts of use of observed and exponential functions of root distribution in soil on water utilization and yield of wheat, simulated with a crop model. Arch. Agron. Soil Sci. 2014, 60, 1533-1542. [CrossRef]

50. Metselaar, K.; Pinheiro, E.; De Jong Van Lier, Q. Lier Mathematical Description of Rooting Profiles of Agricultural Crops and its Effect on Transpiration Prediction by a Hydrological Model. Soil Syst. 2019, 3, 44. [CrossRef]

51. Müller, U. Auswertungsmethoden im Bodenschutz. In Dokumentation zur Methodenbank des Niedersächsischen Bodeninformationssystems (NIBIS), 7th ed.; Schweizerbart: Stuttgart, Germany, 2004.

52. Landl, M.; Schnepf, A.; Uteau, D.; Peth, S.; Athmann, M.; Kautz, T.; Perkons, U.; Vereecken, H.; VanderBorght, J. Modeling the Impact of Biopores on Root Growth and Root Water Uptake. Vadose Zone J. 2019, 18, 1-20. [CrossRef]

53. Ayad, J.Y.; Al-Abdalla, A.M.; Saoub, H.M. Variation in Root Water and Nitrogen Uptake and their Interactive Effects on Growth and Yield of Spring Wheat and Barley Genotypes. Int. J. Bot. 2010, 6, 404-413. [CrossRef]

54. White, C.A.; Sylvester-Bradley, R.; Berry, P.M. Root length densities of UK wheat and oilseed rape crops with implications for water capture and yield. J. Exp. Bot. 2015, 66, 2293-2303. [CrossRef] [PubMed]

55. Yamaguchi, J.; Tanaka, A. Quantitative observation on the root system of various crops growing in the field. Soil Sci. Plant Nutr. 1990, 36, 483-493. [CrossRef]

56. Amato, M.; Pardo, A. Root length and biomass losses during sample preparation with different screen mesh sizes. Plant Soil 1994, 161, 299-303. [CrossRef]

57. Severini, A.D. Root Depth: A Trait to Increase Water Use and Yield of Wheat. Ph.D. Thesis, Research School of Biology, The Australian National University, Canberra, ACT, Australia, 2016. [CrossRef]

58. Ericson, L.; Mattsson, L. Soil and Crop Management Impact on SOC and Physical Properties of Soils in Northern Sweden. In Global Climate Change and Cold Regions Ecosystems. Advances in Soil Science; Lal, R., Kimble, J.M., Stewart, B.A., Eds.; Lewis Publishers: Boca Raton, FL, USA, 2000; pp. 135-148.

59. Nemeth, T. Nitrogen balance studies in a long-term crop rotation field experiment. In Progress in Nitrogen Cycling Studies; Van Cleemput, O., Hofman, G., Vermoesen, A., Eds.; Developments in Plant and Soil Sciences, Springer: Dordrecht, The Netherlands, 1996; Volume 68, pp. 343-346. [CrossRef]

(C) 2020 by the authors. Licensee MDPI, Basel, Switzerland. This article is an open access article distributed under the terms and conditions of the Creative Commons Attribution (CC BY) license (http://creativecommons.org/licenses/by/4.0/). 